\title{
Assessment of splenic function
}

\author{
A. P. N. A. de Porto • A. J. J. Lammers • R. J. Bennink • \\ I. J. M. ten Berge • P. Speelman • J. B. L. Hoekstra
}

Received: 24 June 2010 / Accepted: 17 August 2010 / Published online: 19 September 2010

(C) The Author(s) 2010. This article is published with open access at Springerlink.com

\begin{abstract}
Hyposplenic patients are at risk of overwhelming post-splenectomy infection (OPSI), which carries mortality of up to $70 \%$. Therefore, preventive measures are warranted. However, patients with diminished splenic function are difficult to identify. In this review we discuss immunological, haematological and scintigraphic parameters that can be used to measure splenic function. IgM memory B cells are a potential parameter for assessing splenic function; however, more studies are necessary for its validation. Detection of Howell-Jolly bodies does not reflect splenic function accurately, whereas determining the percentage of pitted erythrocytes is a well-evaluated method and seems a good first-line investigation for assessing splenic function. When assessing spleen function, ${ }^{99 \mathrm{~m}} \mathrm{Tc}$-labelled, heat-altered, autologous erythrocyte scintigraphy with multimodality single
\end{abstract}

A. P. N. A. de Porto $(\bowtie) \cdot$ A. J. J. Lammers $\cdot$ P. Speelman Department of Infectious Diseases, Tropical Medicine and AIDS, G2-105, Academic Medical Center,

Meibergdreef 9 ,

1105 AZ Amsterdam, Netherlands

e-mail: alexander.deporto@student.uva.nl

R. J. Bennink

Department of Nuclear Medicine, Academic Medical Center, Meibergdreef 9,

1105AZ Amsterdam, Netherlands

I. J. M. ten Berge

Department of Internal Medicine, Nephrology Unit,

Academic Medical Center,

Meibergdreef 9 ,

1105AZ Amsterdam, Netherlands

J. B. L. Hoekstra

Department of Internal Medicine, Academic Medical Center,

Meibergdreef 9,

1105AZ Amsterdam, Netherlands photon emission computed tomography (SPECT)-CT technology is the best approach, as all facets of splenic function are evaluated. In conclusion, although scintigraphic methods are most reliable, they are not suitable for screening large populations. We therefore recommend using the percentage of pitted erythrocytes, albeit suboptimal, as a first-line investigation and subsequently confirming abnormal readings by means of scintigraphy. More studies evaluating the value of potentially new markers are needed.

\section{Introduction}

The spleen is the largest lymphoid organ in the human body. Its rich and diverse population of immune cells and its ingenious anatomy that enables optimal surveillance and phagocytosis of circulating blood elements play an important role in the defence against pathogens. Table 1 summarizes the different aspects of splenic functions. After splenectomy, patients are at increased risk of overwhelming post-splenectomy infection (OPSI; see Table 2 [1-4].

Apart from patients with a status after splenectomy, there is a much larger group of patients with diminished splenic function. Many diseases are associated with a dysfunctional spleen (Table 3) and the degree of splenic dysfunction varies between patients [13]. For patients suspected to have a spleen with diminished function, it is important to quantify their splenic function in order to assess the risk of developing OPSI. Subsequently, preventive measurements can be taken and, in the case of infection, therapy can be started without delay. In this review we evaluate the methods available to measure splenic function. 
Table 1 Functions of the spleen

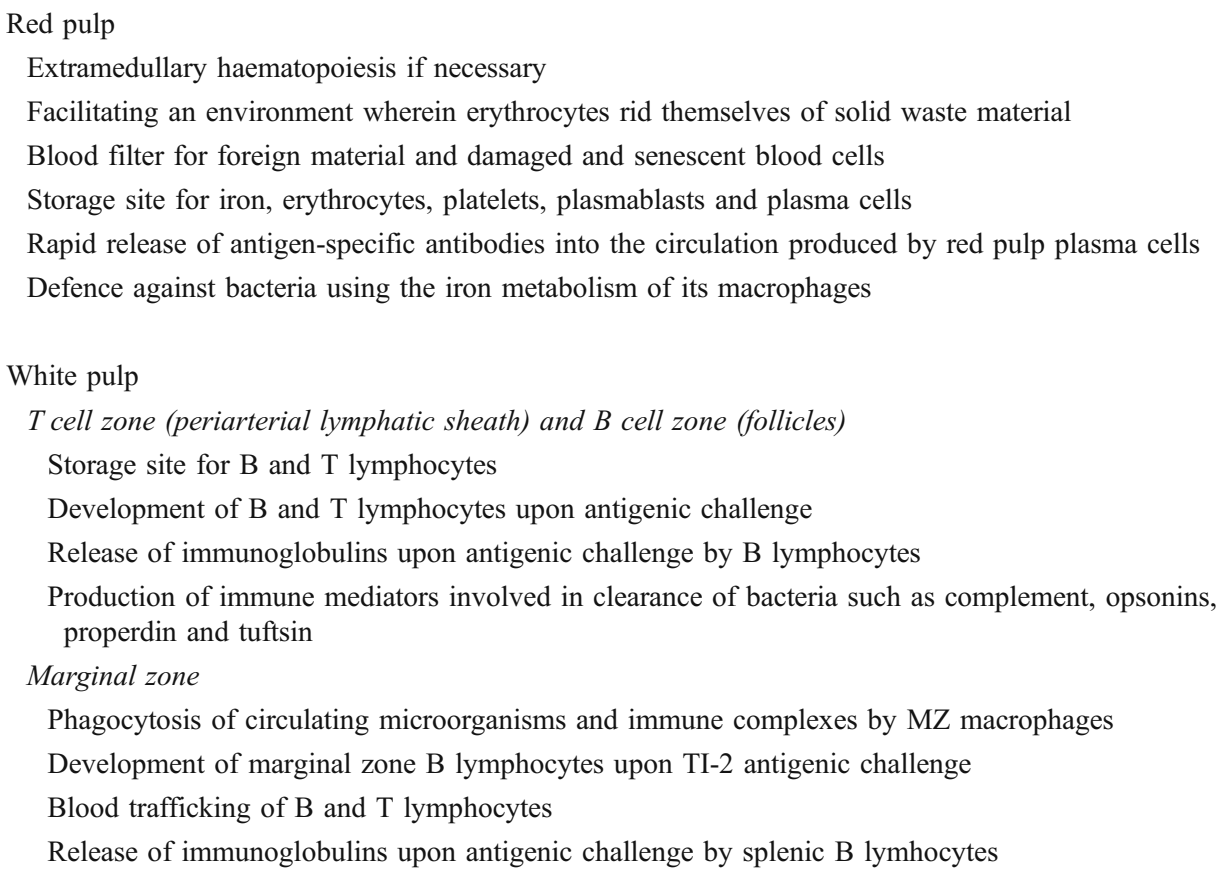

\section{Approaches to measuring splenic function}

Throughout the years, several methods have been developed to quantify the many different functions of the spleen. These methods are based on haematological, immunological and scintigraphic parameters.

\section{Haematological parameters}

Haematological methods reflect the capacity of the spleen to phagocytose deviant erythrocytes and to facilitate an environment wherein erythrocytes rid themselves of solid waste material $[14,15]$. In the event of splenic dysfunction

Table 2 Overwhelming post-splenectomy infection

\begin{tabular}{ll}
\hline Factor & Description \\
\hline Background & After splenectomy, patients are at risk of overwhelming infection. This syndrome is called overwhelming \\
post-splenectomy infection (OPSI) or post-splenectomy sepsis (PSS). Patients with functional asplenia are also at risk \\
of this syndrome. \\
OPSI is characterised by a mild onset with flu-like symptoms such as low-grade fever, chills, muscle aches and \\
nausea. However, a subsequent fast deterioration may occur in hours rather than days, leading to fulminant sepsis, \\
disseminated intravascular coagulation and multi-organ failure [5]. \\
The incidence of OPSI is estimated to be low, 2-5 per 1,000 asplenic patients per year [6]. The lifetime risk of \\
developing OPSI is estimated to be 5\% [7]. Although more than half of these infections occur within the first 2 years \\
after splenectomy, the risk remains increased lifelong [1, 8]. \\
Although the incidence is low, mortality is high. Numbers in the literature vary between 50 and $70 \%$ [1, 3]. Notably, \\
Incidence \\
Encapsulated bacteria are important causative organisms of OPSI. S. pneumoniae causes $70 \%$ of bacteraemic episodes \\
after splenectomy [3]. Other pathogens responsible for OPSI are H. influenzae, N. meningitidis, E. coli and \\
Pseudomonas. \\
To prevent OPSI several preventive measures should be taken, such as immunisation against the encapsulated bacteria \\
S. pneumoniae, H. influenzae B and $N$. meningitidis C. Furthermore, patients should use continuous prophylactic \\
antibiotics during the first 2 years after splenectomy and have on-demand antibiotics to use in case of (suspected) \\
infection [10-12].
\end{tabular}


Table 3 Causes of hyposplenism (adapted from William and Corazza, Table 1 [13])

\begin{tabular}{|c|c|}
\hline Category & Condition \\
\hline Congenital disorders & $\begin{array}{l}\text { Congenital asplenia (isolated) } \\
\text { Ivemark's syndrome } \\
\text { Stormorken's syndrome } \\
\text { Autoimmune polyendocrinopathy- } \\
\text { candidiasis-ectodermal dystrophy } \\
\text { (APECED) syndrome } \\
\text { Fetal hydantoin syndrome } \\
\text { Congenital cyanotic heart disease } \\
\text { Normal and premature neonates }\end{array}$ \\
\hline Sickle haemoglobinopathies & $\begin{array}{l}\text { SS } \\
\text { SC } \\
\text { S/B thalassemia } \\
\text { SE } \\
\text { SO Arab } \\
\text { SD Los Angeles }\end{array}$ \\
\hline Gastrointestinal diseases & $\begin{array}{l}\text { Coeliac disease } \\
\text { Ulcerative colitis } \\
\text { Crohn's disease } \\
\text { Dermatitis herpetiformis } \\
\text { Tropical sprue } \\
\text { Whipple's disease } \\
\text { Idiopathic ulcerative enteritis } \\
\text { Intestinal lymphangiectasis }\end{array}$ \\
\hline Hepatic disorders & $\begin{array}{l}\text { Alcoholic liver disease } \\
\text { Chronic active hepatitis } \\
\text { Liver cirrhosis and portal hypertension } \\
\text { Primary biliary cirrhosis }\end{array}$ \\
\hline Autoimmune disorders & $\begin{array}{l}\text { Systemic lupus erythematosis } \\
\text { Discoid lupus } \\
\text { Antiphospholipid syndrome } \\
\text { Vasculitis } \\
\text { Rheumatoid arthritis } \\
\text { Glomerulonephritis } \\
\text { Sjögren's syndrome } \\
\text { Mixed connective tissue disease } \\
\text { Graves' disease } \\
\text { Hashimoto's thyreoiditis } \\
\text { Multiple sclerosis }\end{array}$ \\
\hline $\begin{array}{l}\text { Haematological/neoplastic } \\
\text { disorders }\end{array}$ & $\begin{array}{l}\text { Bone marrow transplantation } \\
\text { Graft versus host disease } \\
\text { Acute leukaemias } \\
\text { Chronic lymphocytic leukaemia } \\
\text { Non-Hodgkin's lymphoma } \\
\text { Essential thrombocythaemia } \\
\text { Systemic mastocytosis } \\
\text { Sézary syndrome } \\
\text { Pure red cell asplenia } \\
\text { Fanconi syndrome }\end{array}$ \\
\hline
\end{tabular}

Table 3 (continued)

\begin{tabular}{ll}
\hline Category & Condition \\
\hline & Advanced breast cancer \\
& Haemangiosarcoma of the spleen \\
& Haemangioendothelioma of the spleen \\
& Malignant histiocytosis \\
Sepsis/infectious diseases & Disseminated meningeococcaemia \\
& Acquired immunodeficiency syndrome \\
Circulatory disorders & Splenic artery thrombosis \\
& Splenic vein thrombosis \\
& Coeliac artery thrombosis \\
& Old age \\
& Alcoholism \\
Miscellaneous & Sarcoidosis \\
& Amyloidosis \\
& Methyldopa administration \\
& Hypopituitarism \\
& Selective IgA deficiency \\
& Primary pulmonary hypertension \\
& Splenic irradiation \\
& Thorotrast exposure \\
& Total parenteral nutrition \\
& $?$ High-dose corticosteroids \\
& Surgical splenectomy \\
&
\end{tabular}

these capacities are impaired, which results in an increase in abnormal circulating red blood cells. Furthermore, large amounts of thrombocytes and leukocytes normally reside in the spleen. Circulating thrombocyte- and leukocyte counts can either be increased or decreased, indicative of hyposplenism in a patient with a dysfunctional spleen (for example, thrombocytosis in asplenia and thrombopaenia associated with splenomegaly) [13, 16].

One of the first methods available to evaluate splenic function was the detection of erythrocytes containing Howell-Jolly bodies, using a light microscope viewing a stained peripheral blood smear [17, 18]. Howell-Jolly bodies are basophilic DNA remains from the nucleus of the erythrocyte precursor cell. Normally, upon leaving the bone marrow, the erythrocyte precursor cell expels its nucleus. In some erythrocytes, however, a small portion of DNA remains. Normally, the spleen clears the erythrocyte of these nuclear remnants or removes the erythrocytes from the circulation, but when the spleen is absent or has a decreased function, these Howell-Jolly body-containing erythrocytes remain in the circulation. A recently developed method uses flow cytometry to quantify the amount of erythrocytes containing Howell-Jolly bodies [19]. 
Other abnormalities that can be seen on peripheral blood smears of patients with absent or diminished splenic function are acanthocytes (spur cells), target cells (codocytes: erythrocytes with a pattern of central staining, a ring of pallor and an outer ring of staining), haemoglobin remnants (Heinz bodies), siderocytes and iron granulocytes (Pappenheimer bodies) [13, 16] .

In individuals with a dysfunctional or absent spleen the membrane of erythrocytes appears to contain so called "pits" when studied with interference phase microscopy [20]. With electron microscopy it was shown that these "pits" are in fact large vacuoles (about $300 \mathrm{~nm}$ in diameter) beneath or attached to the plasma membrane. These vacuoles have low optical density, because of waste material contained in the erythrocyte, such as ferritine, haemoglobin and rest material of mitochondria and membranes $[14,15,21]$. In case of normal splenic function, pits are seen in $0-4 \%$ of the erythrocytes $[20,22,23]$. A pit count above $4 \%$ has been associated with hyposplenism, although asplenia or clinically relevant hyposplenism is most often associated with much higher values, ranging from 15 to $70 \%$ [22, 24, 25]. Casper et al. noted that in 5 patients with sickle cell disease who developed sepsis and/ or meningitis, pit counts were higher than $15 \%$ and therefore the authors suggested this as a cut-off value for significant splenic dysfunction [23]. The same cut-off value was suggested by Corazza et al., who noted that patients who underwent splenectomy had functional residual splenic tissue when pits counts were beneath $16 \%$ [26].

Another method of evaluating spleen function is counting erythrocytes containing argyrophilic inclusions, where normal values range from 0 to $3 \%$. This method uses a silver stain and in comparison with a normal Wrights stain, the argyrophilic inclusions are shown to be Howell-Jolly bodies, Pappenheimer bodies and other inclusions visible in patients with a decreased or absent splenic function [27].

\section{Immunological parameters}

The spleen contains a large amount of immune cells [28]. In comparison to the peripheral blood lymphocyte compartment, the spleen percentually contains more B-cells and less $\mathrm{CD}^{+}$and $\mathrm{CD}^{+} \mathrm{T}$ cells. The percentage of $\mathrm{CD} 8^{+} \mathrm{T}$ cells is higher in the spleen, leading to an inverse CD4/CD8 ratio. Both splenic $\mathrm{CD} 4^{+}$and $\mathrm{CD} 8^{+} \mathrm{T}$ cell populations show a higher number of activated cells and splenic $\mathrm{CD} 8^{+} \mathrm{T}$ cells show a more differentiated cytotoxic $\mathrm{CD} 27^{-} \mathrm{CD} 45 \mathrm{RA}^{+}$ memory phenotype. Thus, the distribution of the different lymphocyte subsets is markedly different between spleen and peripheral blood, inferring an important and distinct role for the spleen in $\mathrm{CD}^{+}$and $\mathrm{CD} 8^{+} \mathrm{T}$ cell activation [29]. After splenectomy, some immunological functions of the spleen can be taken over by other organs, such as the liver, bone marrow and peripheral lymph nodes. Therefore, these functions are not suitable as a reliable parameter for measuring spleen function. However, the spleen plays a specific role in the defence against encapsulated bacteria [1-4]. This is mainly related to the marginal zone (MZ) containing marginal zone B cells (MZ B cells) and macrophages. Marginal zone macrophages are able to capture whole encapsulated bacteria from the circulation and subsequently initiate a humoral immune response [30]. MZ B cells are a distinct B cell lineage that, unlike other B cell lineages, develop and mutate immunoglobin (Ig) receptors during the first years of life without being engaged in any immune response. Upon stimulation with thymus-independent type 2 (TI-2) antigens expressed by encapsulated bacteria, the prediversified MZ B cells can rapidly proliferate and differentiate into antigen-presenting cells or into IgM-, IgG-, and IgA-secreting plasma cells, circulating for several months. MZ B cells do not differentiate into memory cells and are therefore part of the (immediate) innate immunity against invading pathogens [31-33].

Marginal zone B cells do not only reside in the MZ, but are also present in the circulation and in other lymphoid tissue [34-36]. The spleen is, however, essential for the maintenance of the MZ B cell population, as appears from a decrease in MZ B cell counts after splenectomy. In contrast to one report [31], other studies have shown that young patients with congenital asplenia have a normal blood MZ B cell population, whereas this circulating MZ B cell subset fails to expand in older asplenic individuals [32, 37]. Therefore, the amount of circulating MZ B cells may be an indication of immunological function of the spleen. The effect of diminished spleen function on the composition of naïve, memory and effector (antigen-specific) T cells in the circulation is not yet known. Decreased numbers of circulating memory $\mathrm{B}$ cells have been described in patients with diminished splenic function [31,32,37], although this might be due to a decrease only in IgM memory B cells rather than in other B memory cells [31, 37].

Some studies have described tuftsin as a potential marker for immunological spleen function, since production of this peptide is mainly dependent on the spleen $[38,39]$. Tuftsin is a tetrapeptide with protective bactericidal characteristics, as it has been shown to stimulate phagocytosis by neutrophils and macrophages [40]. Decreased serum levels of tuftsin are seen in splenectomised patients $[38,39]$ and in patients suffering from sickle cell disease [41] and coeliac disease [42].

\section{Scintigraphic parameters}

Like haematological parameters, scintigraphic parameters use the capacity of the spleen to filter the blood of deviant 
cells and particles to measure its activity. The radiopharmaceutical most commonly used for this purpose is technetium-99m $\left({ }^{99 \mathrm{~m}} \mathrm{Tc}\right)$-labelled, heat-altered, autologous erythrocytes, which have replaced the previously commonly used ${ }^{99 \mathrm{~m}} \mathrm{Tc}-$ labelled sulphur colloids [43-48]. ${ }^{99 \mathrm{~m}} \mathrm{Tc}-$ labelled sulphur colloid scintigraphy has been used for visualisation of the phagocytic function of the liver and spleen and was once a common study for evaluating for the presence or absence of neoplastic disease, cirrhosis or portal hypertension, being largely supplanted by other modalities like ultrasonography, (PET)-CT or MRI to date [49]. For the assessment of spleen function or the presence of an accessory spleen, ${ }^{99 \mathrm{~m}} \mathrm{Tc}-$ labelled, heat-altered, autologous erythrocyte scintigraphy is now recommended, because, in contrast to sulphur colloid scintigraphy, sensitivity is not hampered by the relatively high liver uptake [43-48, 50]. Sulphur colloids are captured by phagocytosis, whereas autologous, heat-altered erythrocytes are sequestrated by the normal spleen $[50,51]$. The normal spleen accumulates about $90 \%$ of injected autologous, heat-altered erythrocytes, in contract to $10 \%$ of injected sulphur colloids, which are mainly phagocytosed by the liver [50]. After intravenous re-injection of these cells, splenic function can be determined by:

1. Measuring the clearance rate of the injected cells from the circulation by analysing blood samples using a gamma well-counter

2. Determining the splenic uptake either solely or by determining the spleen-to-liver uptake ratio using a gamma probe or camera

Besides quantitative information on splenic function, planar or dynamic scintigraphy enables visualisation of organ function. In addition to planar scintigraphy, modern multimodality single photon emission computed tomography (SPECT)-CT gamma cameras enable assessment of both function and anatomy (organ volume and structure) within a single investigation, potentially introducing clinically useful parameters like organ-specific functional volumes [52].

Alternatively, unaltered autologous or donor erythrocytes or platelets can be radio-labelled for assessment of pathological sequestration in the spleen in patients with low peripheral cell counts, such as in idiopathic thrombocytopaenic purpura or auto-immune anaemia [43, 50, 53-55]

\section{Different approaches compared}

As there are many approaches to assessing splenic function, the question arises as to which method is most reliable and which is best for clinical use. Knowledge about correlation and functionality of the different available methods is required before a deliberate decision on which method to use can be made. In the next few paragraphs we give an overview of studies comparing the haematological, immunological and scintigraphic parameters in the measurement of splenic function.

\section{Scintigraphic parameters compared}

Although ${ }^{99 \mathrm{~m}} \mathrm{Tc}$-labelled, heat-altered, autologous erythrocytes as well as ${ }^{99 \mathrm{~m}} \mathrm{Tc}$-labelled sulphur colloids have been used in studies on splenic function, not much recent data can be found on their correlation when determining the amount of functional splenic tissue. When computing splenic volumes based on planar scintigraphy in two groups of coeliac patients, splenic volumes derived from ${ }^{99 \mathrm{~m}} \mathrm{Tc}$ labelled sulphur colloid scintigraphy correlated well with those from ${ }^{99 \mathrm{~m}} \mathrm{Tc}$-labelled, heat-altered erythrocyte scintigraphy [56]. Furthermore, there was a good correlation between volume of functional splenic tissue and splenic function measured using ${ }^{99 \mathrm{~m}} \mathrm{Tc}$-labelled heat-altered erythrocyte clearance rates from the circulation. Another publication by Smart et al. in patients with mainly inflammatory bowel disease (IBD) showed a strong correlation between clearance of the cells from the circulation and functional spleen volume, with a large variation around the regression line, leading to the conclusion that functional spleen size determination was not able to replace measurement of the rate of heat-altered erythrocyte clearance from the circulation in the assessment of hyposplenism [57]. However, these studies were performed in the pre-tomographic and ultrasonographic era using planar imaging for volume calculation, making it less reliable. Furthermore, only functioning spleen was visualised and eligible for volume calculation, implying a direct correlation between function and size $[57,58]$

A more recent study by Gotthardt et al. showed that spleen-liver ratios as soon as $10 \mathrm{~min}$ after reinjection of ${ }^{99 \mathrm{~m}} \mathrm{Tc}$-labelled, heat-altered erythrocytes reliably predict spleen function in IBD patients when compared to the rate of clearance of the cells from the circulation. The spleenliver ratio measured with ${ }^{99 \mathrm{~m}} \mathrm{Tc}$-labelled sulphur colloids showed no correlation with the clearance of the ${ }^{99 \mathrm{~m}} \mathrm{Tc}$ labelled, heat-altered erythrocytes [59].

Scintigraphic and haematological parameters compared

The correlation between haematological parameters and scintigraphic parameters has been studied more accurately. In patients with sickle cell disease (SCD), a correlation was found between the uptake of ${ }^{99 \mathrm{~m}} \mathrm{Tc}$-labelled sulphur colloid by functional splenic tissue and the percentage of pitted erythrocytes [23-25]. In a study by Pearson et al. amongst 64 children with homozygous SCD between 8 and 13 months of age, it was found that sensitivity, specificity 
and predictive values were all between $90 \%$ and $98 \%$ when correlating uptake with a percentage of pitted erythrocytes of less than 3.5\% [24]. Another study by Lane et al. described patients with heterozygous SCD (HbSC), where it was demonstrated that pit counts of more than $20 \%$ were indicative of functional asplenia, whereas pit counts lower than $20 \%$ were associated with normal or near normal splenic function [25]. Furthermore, in a study of patients with coeliac disease and dermatitis herpetiformis, a correlation was found between the percentage of pitted erythrocytes and the size of functioning splenic tissue, as measured by using ${ }^{99 \mathrm{~m}} \mathrm{Tc}$-labelled, autologous, heataltered erythrocytes rather than sulphur colloids [22]. In this same group of patients, a significant correlation was found between the percentage of pitted erythrocytes and the clearance rate of ${ }^{99 \mathrm{~m}} \mathrm{Tc}$-labelled, heat-altered erythrocytes. However, another study describing patients with megaloblastic anaemia and iron-deficient anaemia, which are rare causes of hyposplenia, no correlation was found between the percentages of pitted erythrocytes and the blood clearance rate, splenic uptake values and splenic volumes [60]. An explanation for these results could not be given by the authors; however, they state that erythrocyte pits may be heterogeneous in origin, composition, or removal kinetics and may be different in individuals who are hyposplenic for various reasons.

The presence of the Howell-Jolly bodies has historically been associated with diminished splenic function. However, Howell-Jolly bodies have been shown not to correlate with blood clearance of the ${ }^{99 \mathrm{~m}} \mathrm{Tc}$-labelled, heat-altered erythrocytes $[58,59]$. Similar results were obtained using ${ }^{51}$ chromium-labelled heat-altered erythrocytes [61]. The presence of Howell-Jolly bodies did also not correlate with the spleenliver activity ratio measured with either ${ }^{99 \mathrm{~m}} \mathrm{Tc}$-labelled, heataltered erythrocytes or ${ }^{99 \mathrm{~m}} \mathrm{Tc}$-labelled sulphur colloids [59].

\section{Haematological parameters compared}

Although there is discussion in the literature, it was found that the percentage of erythrocytes containing Howell-Jolly bodies correlated with the percentage of pitted erythrocytes $[23,62]$. This correlation, however, was only present at pit counts higher than $8 \%$ and when at least 10,000 erythrocytes were examined. Mild cases of hyposplenism could not be detected by determining percentages of erythrocytes with Howell-Jolly bodies, since a pit count above $4 \%$ is indicative of hyposplenism. No note was made of what percentage of erythrocytes containing Howell-Jolly bodies indicates hyposplenism [62].

The argyrophilic inclusion-positive erythrocyte count has sensitivity of $88.9 \%$ and specificity of $97.1 \%$ for splenic dysfunction when using the percentage of pitted erythrocytes as a gold standard [27].
Immunological and haematological parameters compared

Because the amount of circulating IgM memory B cells was first described in 2005 as a method of quantifying splenic hypofunction, research on this subject is still limited. Two studies describe a correlation between the amount of circulating IgM memory B cells and the percentage of pitted erythrocytes in treated patients with coeliac disease and IBD $[37,63]$. In one study, patients with IBD were divided into either having a decreased splenic function ( $>4 \%$ pitted erythrocytes) or having a normal splenic function ( $<4 \%$ pitted erythrocytes) and both were compared with a control group [37]. Patients with decreased splenic function were shown to have lower amounts of circulating memory B cells, mainly IgM memory B cells, compared with healthy controls as well as individuals classified as having normal splenic function. Furthermore, IgM memory B cells were shown to be completely absent in the peripheral blood of splenectomised patients. As described above, serum tuftsin might be indicative of splenic function, although not much research on the subject has been published. This potential marker was studied in 52 untreated patients with coeliac disease [42]. In accordance with the study on IgM memory B cells, patients were divided into groups based on pit count. It was found that hyposplenic as well as eusplenic coeliac patients had significantly lower tuftsin activity than healthy controls, but significantly higher than splenectomised patients. There was less tuftsin activity in hyposplenic patients than in eusplenic patients. Furthermore, a correlation was found between serum tuftsin activity and the percentage of pitted erythrocytes.

\section{Discussion}

Knowledge about splenic function is important, since patients with an absent spleen or decreased splenic function are at risk of developing severe infections with a high mortality rate. Quantification of spleen function could become an important tool for physicians in their decisionmaking regarding the need for preventive measures. However, when assessing splenic function in a clinical setting, physicians should be aware of the multiple facets of spleen function (as described in Table 1) and thus the different possible approaches to determining splenic function.

In many diseases associated with splenic hypofunction such as sickle cell disease, coeliac disease, IBD and systemic lupus erythematosis, splenic function changes as the underlying disease activity alters [56, 57, 61, 64-67]. It has been suggested that these changes in splenic function are due to two components of splenic hypofunction in active disease: first, impaired splenic function, which may 
deteriorate during high disease activity, but may improve with treatment, and second, splenic atrophy, which may lead to irreversible loss of volume and therefore also irreversible loss of function. Illustrating this phenomenon, two patients are described in whom the size of the functional splenic tissue did not alter during relapse of the disease, causing the hyposplenia, while the clearance rate of heat-damaged autologous erythrocytes was prolonged $[56,57]$. Shifts in the splenic volume-function relation can also occur in other situations, such as splenomegaly which is frequently observed in hyposplenic heterozygote sicklecell patients [68]. Also, hypersplenism with homogeneous organ function, splenic infarction, splenomas (regenerating nodules) [69] or transition to autosplenectomy can shift the splenic volume-function relation [70].

Because functional splenic tissue can be temporarily impaired during increased disease activity, whereas splenic atrophy is permanent, it is important to be informed about function as well as the actual volume of the organ. To measure the activity of the functional compartment of the spleen, ${ }^{99 \mathrm{~m}} \mathrm{Tc}$-labelled heat-altered autologous erythrocyte scintigraphy with quantification of spleen uptake seems the most appropriate technique. This method is well evaluated, especially in comparison with other methods [59]. Clearance rates of ${ }^{99 \mathrm{~m}} \mathrm{Tc}-$ labelled, heat-altered, autologous erythrocytes from the circulation should be considered carefully, since this is not solely dependent on splenic sequestration as the liver also partially participates in this process. Although liver uptake of ${ }^{99 \mathrm{~m}} \mathrm{Tc}$-labelled, heataltered erythrocytes is low in controls, absolute liver uptake can vary considerably, potentially affecting secondary parameters like the spleen-liver ratio [52]. Consequently, as the spleen is not the unique sequestering organ, with variability of liver uptake that possibly increases when splenic function is diminishing, this phenomenon may affect the axiom that measured blood clearance of cells reflects pure spleen function. Therefore, assessment of pure splenic uptake in function of the administered dose might be a better strategy.

Performing ${ }^{99 \mathrm{~m}} \mathrm{Tc}$-labelled, heat-altered erythrocyte scintigraphy on state-of-the-art SPECT-CT gamma cameras will enable the combination of both function and anatomy (volume) within a single investigation with the possibility of accounting for the exact organ volume and the volume of functional organ tissue within the organ.

The large amount of potential hyposplenic patients (Table 3) makes it almost impossible to evaluate splenic function by means of scintigraphy in every patient. Laborious preparation (cell isolation, denaturation and labelling), gamma (SPECT/CT) camera availability and even the radiation burden - albeit low-requires selection of patients eligible for this advanced technique. To screen a large group of potential hyposplenic patients, a more economical, simple and easily accessible method without radiation burden is needed. An alternative is counting the percentage of pitted erythrocytes, which is also well evaluated [22-25, 60]. It is quick, cheap and non-invasive. However, interference phase microscopy needs to be available as well as trained personnel. It should also be considered that erythrocyte pits may be heterogeneous with regard to their origin, composition, or removal kinetics [60]. Percentages indicating hyposplenism may therefore be different in individuals who are hyposplenic for various reasons. Detection of Howell-Jolly bodies does not seem to be a reliable method of evaluating splenic function, as correlation with other methods is poor [59]. However, measuring the percentage of Howell-Jolly bodies via flow cytometry is a potentially more reliable parameter as large amounts of erythrocytes can be screened [19]. The percentage of argyrophilic inclusion-positive erythrocytes is a parameter that is simple and seems reliable [27]. Measuring the percentages of both Howell-Jolly bodies by flow cytometry as well as argyrophilic inclusion-positive erythrocytes does not require special equipment. However, both methods require extensive validation. More studies evaluating the value of potentially new (immunological) markers are needed. Measuring the amount of IgM memory B cells seems a promising method, giving the opportunity to measure the susceptibility to infection in a more direct way $[31,37,63]$. Until these new methods have been validated, quantification of the percentages of pitted erythrocytes seems most reliable to screen for potential hyposplenic patients. Abnormal readings can subsequently be confirmed by scintigraphy.

\section{Conclusion and recommendations}

Large studies comparing all available methods in various patient populations with splenic hypofunction are lacking, and data on sensitivity and specificity are scarce. To measure splenic function accurately it is important to have knowledge about the volume and function of the active splenic tissue as well as the volume of the organ itself. Function in splenic tissue can temporarily be decreased because of increased disease activity, while the spleen might actually still be partially functioning and is not in state of atrophy. Assessment of spleen function using ${ }^{99 \mathrm{~m}} \mathrm{Tc}$-labelled, heat-altered, autologous erythrocyte scintigraphy combined with a multimodality SPECT-CT approach seems best for this purpose as all facets of splenic function are evaluated. Measuring the clearance rates of $99 \mathrm{~m}$ Tc-labelled, heat-altered, autologous erythrocytes from the circulation should be considered carefully as a method of assessing splenic function, since this is not solely dependent on spleen activity. 
The population of hyposplenic patients is too large to screen by the use of scintigraphy as a first-line investigation. Therefore, a cheaper, simpler, more accessible method is necessary. At present, we recommend using the percentage of pitted erythrocytes for this purpose, and refer patients with abnormal percentages for scintigraphy. Finally, more studies evaluating the value of potentially new (immunological) markers are needed.

Open Access This article is distributed under the terms of the Creative Commons Attribution Noncommercial License which permits any noncommercial use, distribution, and reproduction in any medium, provided the original author(s) and source are credited.

\section{References}

1. Styrt B (1990) Infection associated with asplenia: risks, mechanisms, and prevention. Am J Med 88:33N-42N

2. Singer DB (1973) Postsplenectomy sepsis. Perspect Pediatr Pathol $1: 285-311$

3. Holdsworth RJ, Irving AD, Cuschieri A (1991) Postsplenectomy sepsis and its mortality rate: actual versus perceived risks. Br J Surg 78:1031-1038

4. Bisharat N, Omari H, Lavi I, Raz R (2001) Risk of infection and death among post-splenectomy patients. J Infect 43:182-186

5. Okabayashi T, Hanazaki K (2008) Overwhelming postsplenectomy infection syndrome in adults - a clinically preventable disease. World J Gastroenterol 14:176-179

6. Brigden ML, Pattullo A, Brown G (2000) Pneumococcal vaccine administration associated with splenectomy: the need for improved education, documentation, and the use of a practical checklist. Am J Hematol 65:25-29

7. Lynch AM, Kapila R (1996) Overwhelming postsplenectomy infection. Infect Dis Clin North Am 10:693-707

8. Cullingford GL, Watkins DN, Watts AD, Mallon DF (1991) Severe late postsplenectomy infection. Br J Surg 78:716-721

9. Lutwick LI (2010) Infections in asplenic patients. In: Mandell GJ, Bennett JE, Raphael D (eds) Principles and practice of infectious diseases, 7th edn. Churchill Livingstone, Elsevier, pp 3865-3873

10. Working Party of the British Committee for Standards in Haematology Clinical Haematology Task Force. (1996) Guidelines for the prevention and treatment of infection in patients with an absent or dysfunctional spleen. BMJ 7028:430-434

11. Davies JM, Barnes R, Milligan D (2002) Update of guidelines for the prevention and treatment of infection in patients with an absent or dysfunctional spleen. Clin Med 2:440-443

12. Mourtzoukou EG, Pappas G, Peppas G, Falagas ME (2008) Vaccination of asplenic or hyposplenic adults. Br J Surg 95:273-280

13. William BM, Corazza GR (2007) Hyposplenism: a comprehensive review. I. Basic concepts and causes. Hematology 12:1-13

14. Schnitzer B, Rucknagel DL, Spencer HH, Aikawa M (1971) Erythrocytes: pits and vacuoles as seen with transmission and scanning electron microscopy. Science 173:251-252

15. Holroyde CP, Gardner FH (1970) Acquisition of autophagic vacuoles by human erythrocytes. Physiological role of the spleen. Blood 36:566-575

16. Doll DC, List AF, Yarbro JW (1987) Functional hyposplenism. South Med J 80:999-1006

17. Lipson RL, Bayrd ED, Watkins CH (1959) The postsplenectomy blood picture. Am J Clin Pathol 32:526-532

18. Damshek W (1955) Hypersplenism. Bull NY Acad Med 31:113-136
19. Harrod VL, Howard TA, Zimmerman SA, Dertinger SD, Ware RE (2007) Quantitative analysis of Howell-Jolly bodies in children with sickle cell disease. Exp Hematol 35:179-183

20. Holroyde CP, Oski FA, Gardner FH (1969) The "pocked" erythrocyte. Red-cell surface alterations in reticuloendothelial immaturity of the neonate. N Engl J Med 281:516-520

21. Reinhart WH, Chien S (1988) Red cell vacuoles: their size and distribution under normal conditions and after splenectomy. Am J Hematol 27:265-271

22. Corazza GR, Bullen AW, Hall R, Robinson PJ, Losowsky MS (1981) Simple method of assessing splenic function in coeliac disease. Clin Sci (Lond) 60:109-113

23. Casper JT, Koethe S, Rodey GE, Thatcher LG (1976) A new method for studying splenic reticuloendothelial dysfunction in sickle cell disease patients and its clinical application: a brief report. Blood 47:183-188

24. Pearson HA, Gallagher D, Chilcote R, Sullivan E, Wilimas J, Espeland M, Ritchey AK (1985) Developmental pattern of splenic dysfunction in sickle cell disorders. Pediatrics 76:392-397

25. Lane PA, O'Connell JL, Lear JL, Rogers ZR, Woods GM, Hassell KL, Wethers DL, Luckey DW, Buchanan GR (1995) Functional asplenia in hemoglobin SC disease. Blood 85:2238-2244

26. Corazza GR, Tarozzi C, Vaira D, Frisoni M, Gasbarrini G (1984) Return of splenic function after splenectomy: how much tissue is needed? Br Med J (Clin Res Ed) 289:861-864

27. Tham KT, Teague MW, Howard CA, Chen SY (1996) A simple splenic reticuloendothelial function test: counting erythrocytes with argyrophilic inclusions. Am J Clin Pathol 105:548-552

28. Mebius RE, Kraal G (2005) Structure and function of the spleen. Nat Rev Immunol 5:606-616

29. Langeveld M, Gamadia LE, ten Berge IJ (2006) T-lymphocyte subset distribution in human spleen. Eur J Clin Invest 36:250-256

30. Koppel EA, Wieland CW, van den Berg VC, Litjens M, Florquin S, van Kooyk Y, van der Poll T, Geijtenbeek TB (2005) Specific ICAM-3 grabbing nonintegrin-related 1 (SIGNR1) expressed by marginal zone macrophages is essential for defense against pulmonary Streptococcus pneumoniae infection. Eur J Immunol 35:2962-2969

31. Kruetzmann S, Rosado MM, Weber H, Germing U, Tournilhac O, Peter HH, Berner R, Peters A, Boehm T, Plebani A, Quinti I, Carsetti R (2003) Human immunoglobulin M memory B cells controlling Streptococcus pneumoniae infections are generated in the spleen. J Exp Med 197:939-945

32. Weller S, Braun MC, Tan BK, Rosenwald A, Cordier C, Conley ME, Plebani A, Kumararatne DS, Bonnet D, Tournilhac O, Tchernia G, Steiniger B, Staudt LM, Casanova JL, Reynaud CA, Weill JC (2004) Human blood IgM "memory" B cells are circulating splenic marginal zone B cells harboring a prediversified immunoglobulin repertoire. Blood 104:3647-3654

33. Weller S, Reynaud CA, Weill JC (2005) Vaccination against encapsulated bacteria in humans: paradoxes. Trends Immunol 26:85-89

34. Dono M, Zupo S, Leanza N, Melioli G, Fogli M, Melagrana A, Chiorazzi N, Ferrarini M (2000) Heterogeneity of tonsillar subepithelial B lymphocytes, the splenic marginal zone equivalents. J Immunol 164:5596-5604

35. Spencer J, Perry ME, Dunn-Walters DK (1998) Human marginalzone B cells. Immunol Today 19:421-426

36. Liu YJ, Barthelemy C, de Bouteiller O, Arpin C, Durand I, Banchereau J (1995) Memory B cells from human tonsils colonize mucosal epithelium and directly present antigen to $\mathrm{T}$ cells by rapid up-regulation of B7-1 and B7-2. Immunity 2:239-248

37. Di Sabatino A, Rosado MM, Ciccocioppo R, Cazzola P, Morera R, Corazza GR, Carsetti R (2005) Depletion of immunoglobulin $\mathrm{M}$ memory B cells is associated with splenic hypofunction in inflammatory bowel disease. Am J Gastroenterol 100:1788-1795 
38. Spirer Z, Zakuth V, Diamant S, Mondorf W, Stefanescu T, Stabinsky Y, Fridkin M (1977) Decreased tuftsin concentrations in patients who have undergone splenectomy. Br Med J 2:1574-1576

39. Constantopoulos A, Likhite V, Crosby WH, Najjar VA (1973) Phagocytic activity of the leukemic cell and its response to the phagocytosis-stimulating tetrapeptide, tuftsin. Cancer Res 33:1230-1234

40. Najjar VA (1983) Tuftsin, a natural activator of phagocyte cells: an overview. Ann NY Acad Sci 419:1-11

41. Spirer Z, Weisman Y, Zakuth V, Fridkin M, Bogair N (1980) Decreased serum tuftsin concentrations in sickle cell disease. Arch Dis Child 55:566-567

42. Corazza GR, Zoli G, Di SA, Ciccocioppo R, Gasbarrini G (1999) A reassessment of splenic hypofunction in celiac disease. Am J Gastroenterol 94:391-397

43. Ambriz P, Munoz R, Quintanar E, Sigler L, Aviles A, Pizzuto J (1985) Accessory spleen compromising response to splenectomy for idiopathic thrombocytopenic purpura. Radiology 155:793-796

44. Massey MD, Stevens JS (1991) Residual spleen found on denatured red blood cell scan following negative colloid scans. J Nucl Med 32:2286-2287

45. Van Nostrand D, Corley JH, Kyle RW, Stotler RE (1983) Value of selective spleen scintigraphy when liver/spleen image shows equivocal spleen defects: concise communication. J Nucl Med 24:559-562

46. Ramchandran T, Margouleff D, Atkins H (1980) Spleen scanning in humans with Tc-99m-labeled erythrocytes: concise communication. J Nucl Med 21:13-16

47. Armas RR, Thakur ML, Gottschalk A (1980) A simplified method of selective spleen scintigraphy with Tc-99m-labeled erythrocytes: clinical applications. Concise communication. J Nucl Med 21:413-416

48. Ehrlich CP, Papanicolaou N, Treves S, Hurwitz RA, Richards P (1982) Splenic scintigraphy using Tc-99m-labeled heat-denatured red blood cells in pediatric patients: concise communication. $\mathrm{J}$ Nucl Med 23:209-213

49. Hladik WB, Norenberg JP (1996) Radiopharmaceuticals for liver and spleen imaging. In: Henkin RE, Boles MA, Dillehay GL et al (eds) Nuclear medicine. Mosby, Missouri, pp 966-976

50. Armas RR (1985) Clinical studies with spleen-specific radiolabeled agents. Semin Nucl Med 15:260-275

51. Owunwanne A, Halkar R, Al-Rasheed A, Abubacker KC, AbdelDayem H (1988) Radionuclide imaging of the spleen with heat denatured technetium-99m RBC when the splenic reticuloendothelial system seems impaired. J Nucl Med 29:320-323

52. Schmitz R, Hemayat E, Lammers AJJ, de Porto APNA, de Jong J, Bennink RJ (2010) Measurement of splenic function with heatdamaged red blood cells. Eur J Nucl Med Mol Imaging 36:481

53. Demar M, Legrand E, Hommel D, Esterre P, Carme B (2004) Plasmodium falciparum malaria in splenectomized patients: two case reports in French Guiana and a literature review. Am J Trop Med Hyg 71:290-293

54. Pettit JE (1977) Spleen function. Clin Haematol 6:639-656

55. Phom H, Kumar A, Tripathi M, Chandrashekar N, Choudhry VP, Malhotra A, Bal CS (2004) Comparative evaluation of Tc- 99m-heat-denatured RBC and Tc-99m-anti-D IgG opsonized $\mathrm{RBC}$ spleen planar and SPECT scintigraphy in the detection of accessory spleen in postsplenectomy patients with chronic idiopathic thrombocytopenic purpura. Clin Nucl Med 29:403409

56. Robinson PJ, Bullen AW, Hall R, Brown RC, Baxter P, Losowsky MS (1980) Splenic size and function in adult coeliac disease. Br J Radiol 53:532-537

57. Smart RC, Ryan FP, Holdworth CD, Preston FE (1978) Relationship between splenic size and splenic function. Gut 19:56-59

58. Robertson DA, Bullen AW, Hall R, Losowsky MS (1983) Blood film appearances in the hyposplenism of coeliac disease. Br J Clin Pract 37:19-22

59. Gotthardt M, Broker S, Schlieck A, Bauhofer A, Herbst B, Behe M, Corstens FH, Behr TM, Gorg C (2007) Scintigraphy with $99 \mathrm{mTc}$-labeled heat-altered erythrocytes in diagnosing hyposplenia: prospective comparison to $99 \mathrm{mTc}$-labeled colloids and colour-coded duplex ultrasonography. Nuklearmediziner 46:135-140

60. Zago MA, Costa FF, Covas DT, Figueiredo MS, Bottura C (1986) Discrepancy between pit counting and spleen function tests in nutritional anemias and hemoglobinopathy C. Nouv Rev Fr Hématol 28:81-84

61. Ryan FP, Smart RC, Holdsworth CD, Preston FE (1978) Hyposplenism in inflammatory bowel disease. Gut 19:50-55

62. Corazza GR, Ginaldi L, Zoli G, Frisoni M, Lalli G, Gasbarrini G, Quaglino D (1990) Howell-Jolly body counting as a measure of splenic function. A reassessment. Clin Lab Haematol 12:269-275

63. Di Sabatino A, Rosado MM, Cazzola P, Riboni R, Biagi F, Carsetti R, Corazza GR (2006) Splenic hypofunction and the spectrum of autoimmune and malignant complications in celiac disease. Clin Gastroenterol Hepatol 4:179-186

64. Pearson HA, Cornelius EA, Schwartz AD, Zelson JH, Wolfson SL, Spencer RP (1970) Transfusion-reversible functional asplenia in young children with sickle-cell anemia. N Engl J Med 283:334-337

65. Ferster A, Bujan W, Corazza F, Devalck C, Fondu P, Toppet M, Verhas M, Sariban E (1993) Bone marrow transplantation corrects the splenic reticuloendothelial dysfunction in sickle cell anemia. Blood 81:1102-1105

66. Palmer KR, Sherriff SB, Holdsworth CD, Ryan FP (1981) Further experience of hyposplenism in inflammatory bowel disease. Q J Med 50:463-471

67. Dillon AM, Stein HB, English RA (1982) Splenic atrophy in systemic lupus erythematosus. Ann Intern Med 96:40-43

68. Nagel RL, Fabry ME, Steinberg MH (2003) The paradox of hemoglobin SC disease. Blood Rev 17:167-178

69. Mestre-Fusco A, Aguade-Bruix S, Zuccarino F, Boronat-Ferrater M, Rossi S, Andreu J (2008) Sickle cell anemia and functioning splenic tissue: correlation of scintigraphic findings and CT. Clin Nucl Med 33:137-139

70. Zago MA, Bottura C (1983) Splenic function in sickle-cell diseases. Clin Sci (Lond) 65:297-302 